\title{
Komponen Sebuah Perjalanan Wisata (Tour)
}

\author{
I Wayan Wijayasa \\ Akademi Pariwisata Denpasar \\ wijayasa2002@yahoo.com
}

\begin{abstract}
A Tour consists of six important elements. Those are (1) transportation which can be land, sea, or air transportation. (2) Acommodation that can be an expensive resort or a small and simple motor inn. (3) Dining can be a qick-service food, buffet dinner, or table service dining. (4) Sightseeing; which can be a city tour, rural or village tour to historical sites, traditional architecture, or (5) Attraction is actually the most important pulling factor motivation of the tourists' visit to a destination which can be a performance, an adventure activities, etc. (6) Shopping which can be a big super-market, traditional art market, or galleries. A tour plan is made in the form of 3 different itineraries. Those are (1) summary itinerary, (2) Detail Passenger Itinerary or DPI, and (3) Escort itinerary which is also welknown as Manual. A tour itinerary must consider all six elements in accordance with the clients' interests, budget, number, and time alocation for a tour.
\end{abstract}

Keywords: Tour, Itinerary, Elements .

\section{Pendahuluan}

Sebuah paket perjalanan wisata, baik itu domestik maupun internasional memiliki unsurunsur wisata yang sama. Jika dikaitkan dengan unsur-unsur pembentuk sebuah destinasi wisata maka harus ada 4 (empat) unsur utama yang dikenal dengan 4 A's yaitu: (1) Attraction adalah berbagai daya tarik wisata, (2) Access adalah kemudahan mencapai sebuah destinasi wisata, (3) Amenities, adalah sarana prasarana pariwisata termasuk hotel, travel agent, dsbnya dan (4) Anceliaries adalah sarana pendukung seperti bank, moneychanger, tempat berbelanja dsbnya. Artikel ini membahas secara khusus komponen sebuah tur yang harus diorganisasikan dengan baik sehingga sebuah tour menjadi menarik sesuai dengan keinginan atau harapan wisatawannya.

Artikel ini merupakan terjemahan dari salah satu bab dalam buku "The Essentials of Tour Management" yaitu bab yang membahas tentang elemen sebuah tour dengan judul asli "The Elements of a Tour". Terjemahan buku ini begitu penting untuk memberikan gambaran secara detail tentang salah satu aspek dari manajemen perjalanan wisata sehingga bagi pembaca, khususnya mahasiswa memiliki dasar konseptual tentang beberapa aspek atau komponen sebuah tour. Bab ini membahas secara detail jenis-jenis sarana transportasi, jenis dan nama akomodasi, jenis dan gaya jamuan makan, jalan-jalan di destinasi wisata, berbelanja serta melakukan aktivitas wisata atau mengunjungi atraksi wisata tertentu.

\section{Pembahasan}

Pada bagian ini, dua hal akan dibahas yaitu kajian teoretis terhadap elemen-elemen pokok dalam sebuah perjalanan wisata, dan studi kasus pada sebuah paket wisata. Kajian teoretic membahas tentang definisi tour, konsep unsur-unsur yang membangunnya serta teknik mengorganisasikan element-element tersebut kedalam sebuah itinerary.

\subsection{Definisi Sebuah Perjalanan Wisata (Tour)}

Dalam bahasa Inggris, istilah-istilah dalam industri perjalanan lebih dapat dibedakan dengan melihat pilihan kata yang mengandung arti yang berbeda satu dengan yang lainnya, atau mengandung makna yang berbeda dari cakupan pembahasannya; yang satu bersifat lebih umum dan yang satu bersifat lebih khusus. Seperti istilah "Tour" dengan istilah "sightseeing" dimana "Tour" memiliki makna yang lebih luas dari "sigthseeing" yang merupakan bagian 
dari "tour". Berikut adalah kutipan yang diambil dari sebuah buku yang berjudul "Esentials of Tour Management"

"A tour is a combination of Travel elements sold and/or coordinated for a "group" or "individuals" by a tour planner and arranged with itinerary of daily activities, some prepared, and planned for specific date, sold at a price per person is less than an individual person would pay when traveling alone. Tour operators provide the services of coordinating, planning, and executing tours”. (Fay, 1992:2)

Tour didefinisikan sebagai sebuah kombinasi dari unsur-unsur perjalanan yang dijual dan/atau dikordinasikan oleh sebuah perencana perjalanan dan dirancang dengan itinerary aktivitas tiap harinya, beberapa dirancang untuk waktu yang khusus, diual per orang yang harganya lebih murah dari haraga jika wisatawan membeli sendirian. Tour operator bertugas dalam mengkordinasikan, merencanakan, dan menjalankan tournya. Tour, secara umum dapat dibedakan menjadi dua yaitu (1) tour yang memfokuskan pada pengalaman perjalanan kelompok. Tour ini memiliki asumsi bahwa seluruh anggota kelompok akan melakukan aktivitas wisata berlibur atau melakukan aktivitas wisata lainnya secara bersama-sama. (2) Tour yang diselenggarakan dengan maksud utama mendapatkan efisiensi harga transportasi, akomodasi, dan aktivitas lainnya. Tour ini tidak dirancang untuk meningkatkan interaksi antar peserta tetapi lebih pada tujuan memfasilitasi carter transportasi, pemesanan hotel dan sebagainya. Tipe ini memiliki anggapan bahwa tidak semua anggota group memilih aktivitas yang sama pada hari-hari yang sama pula. Tour yang didasarkan pada perjalanan independen disebut dengan independent tour.

Keterampilan yang dibutuhkan adalam mengelola kedua tipe tour ini memiliki kemiripan, akan tetapi mengelola tour group membutuhkan keterampilan lebih.

\subsection{Elemen/Komponen yang Membentuk Sebuah Perjalanan Wisata (Tour)}

Elemen adalah komponen atau aktivitas dasar dari sebuah Tour. Kategorinya meliputi bagian-bagian sebagai berikut:

1. Transportasi

2. Tempat Menginap (Lodging)

3. Tempat Makan (dining)

4. Wisata (Sightseeing/guide service)

5. Atraksi Wisata

6. Shopping

Komponen tersebut dapat dijelaskan dengan lebih detail dalam tabel berikut:

\begin{tabular}{|l|l|l|}
\hline \multicolumn{2}{|c|}{ Komponen dari Sebuah Tour (Paket Wisata) } \\
\hline 1. & Transportation & Details \\
\hline & & Motorcoach \\
\hline & & Minicoach/Van \\
\hline & & School bus \\
\hline & & Air (schedulled) \\
\hline & & Air (Chartered) \\
\hline & & Train \\
\hline 2. & Lodging & Limousine \\
\hline & & Cruise ship \\
\hline & & Hotel \\
\hline & & Motel \\
\hline & & Motor inn \\
\hline & & Resort \\
\hline 3. & Dining & Lodge \\
\hline & & Cruise ship \\
\hline & & Limited service/Quick service \\
\hline
\end{tabular}




\begin{tabular}{|l|l|l|}
\hline & & Specialty/Theme Restaurant \\
\hline 4. & Sightseeing/Guide Service & Cruise ships \\
\hline & & Natural Sites/Park \\
\hline & & Scenic highways and byways \\
\hline 5. & Atraksi Wisata & Guided City and Regional Tours \\
\hline & & Monuments and historical areas \\
\hline & & Themic Transportation \\
\hline & & Amusement Parks \\
\hline & & Museums \\
\hline 6. & Shopping & Historical attractions \\
\hline & & Educational/Cultural Attractions \\
\hline & & Malls \\
\hline & & Specialty Shops \\
\hline
\end{tabular}

Tabel 1

Komponen dari Sebuah Tour (Paket Wisata)

(Sumber : Fay,1992)

Pemahaman tentang komponen tersebut sangat penting bagi individu atau profesional yang berkerja di perusahaan atau industri perjalanan beserta terminologi yang digunakan oleh tour operator. Istilah yang digunakan di industri kadang-kadang digunakan dengan salah atau disalah persepsikan. Berikut adalah penjelasan dari masing-masing komponen tersebut.

\subsubsection{Transportasi}

Transportasi dapat berupa berbagai alat dan metode untuk membawa penumpang dari satu tempat ke tempak berikutnya. Jenis transportasi yang paling umum digunakan untuk tour rombongan adalah motorcoach atau Bus Pariwisata di Indonesia. Perusahaan armada bus ini sudah banyak berbuat untuk kenyamanan penumpang di jalan raya termasuk menyediakan berbagai fasilitas pendukung seperti: toilet yang lengkap, cocktail bar, jendela yang besar serta ruang pengamatan, perlengkapan audio-video, dan sejenisnya. Pada umumnya Bus mengangkut 46-48 penumpang dewasa, memiliki panjang 40 kaki, dan lebar 102 inchi. Sebelum Bus Pariwisata sebagus dan semewah sekarang, bus sekolah juga dimanfaatkan untuk mengangkut wisatawan. Pada saat ini, era deskriminasi konsumen, Bus Pariwisata inilah yang digunakan untuk sarana transportasi wisata, walaupun Bus Sekolah juga kadang-kadang digunakan untuk jemaat gereja atau anak sekolah.

Salah satu mode transportasi masal yang kurang populer saat ini untuk pariwisata adalah kereta api (train). Padahal mode transportasi ini dapat menawarkan pengalaman melihat pemandangan pedesaan dalam jarak atau wilayah yang luas dengan kecepatan tinggi dan jarak tempuh di darat yang panjang melintasi wilayah kota dan pedesaan. Tetapi jarak rata-rata perjalanan wisata adalah kurang dari 700-800 mil dan hanya menggunakan transportasi bus pariwisata. Perjalanan yang lebih jauh antar negara dan bahkan antar benua menggunakan mode transportasi udara. Transportasi udara merupakan transportasi pilihan terbaik untuk membawa penumpang dalam jumlah besar dan jarak yang jauh serta waktu tempuh yang relatif singkat. Satu-satunya sisi buruk dari perjalanan dengan pesawat udara adalah keluar dan masuk dari satu bandara ke bandara lain serta pesawat ini tidak dapat digunakan sendiri. Transportasi udara yang umum digunakan adalah pesawat yang vjadwal penerbangannya sudah diatur sedemikian rupa, hanya beberapa pesawat dapat dicharter secara menyeluruh dari tempat duduk, makanan, awak dan crew airline serta tempat parkir di bandara. Beberapa perjalanan wisata menggunakan gabungan beberapa alat transportasi yaitu transportasi udara digabungkan dengan beberapa transportasi darat atau laut seperti bus pariwisata, limosin, kereta api, dan lain sebagainya. Perjalanan wisata yang menggabungkan beberapa mode transportasi disebut dengan Intermodal tour. 
Salah satu alat transportasi yang memberikan pengalaman menyeluruh dan makin populer adalah Kapal Pesiar. Alat transportasi ini mengandung keseluruhan aspek dari sebuah perjalanan wisata atau tour dari, tempat menginap, atraksi wisata, tempat makan, tempet berbelanja, dan jalan-jalan. Kapal pesiar juga dilengkapi dengan sukoci-sukoci kecil yang dapat mengantarkan wisatawan ke pelabuhan. Satu-satunya yang kurang adalah transportasi dari dan ke kapal pesiar dan ini membutuhkan sarana transportasi tambahan lainnya. Untuk rombongan khusus, jasa transportasi mobil atau minibus limousin juga diguakan, akan tetapi kebanyakan tidak menggunakan jasa transportasi mewah ini karena tidak masuk perhitungan harga per orang yang ekonomis.

\subsubsection{Lodging}

Istilah lodging mengacu pada setiap jasa yang menyediakan tempat berteduh atau bermalam kepada wisatawan. Definisi ini mencakup guests house, hotel, motel, pondok wisata dan lain sebagainya. Rata-rata jumlah peserta sebuah wisata rombongan terdiri dari 15-25 pasangan yang terpisah, sehingga properti yang memiliki kamar kurang dari itu tidak cocok digunakan untuk tempat menginap wisatawan rombongan. Jumlahnya bersifat fluktuatif. Jumlah peserta tidak dapat ditentukan dengan pasti jauh-jauh hari sebelumnya, Syarat sebuah akomodasi dapat digunakan untuk akomodasi wisata rombongan paling tidak memiliki kamar 20-25 kamar sehingga dapat menampung jumlah maksimal rombongan. Berikut adalah jenisjenis akomodasi wisata yang digunakan oleh perencana perjalanan wisata:

1. Inn.

"Inn" merupakan istilah generik dan mengandung makna sejarah yang ada sebelum istilah hotel ada, dan jangan disalah artikan dengan penggunaannya dengan istilah "country inn". Penggunaan kata "inn" yang digabungkan dengan nama perusahaan seperti "Hpliday inn", "Ramada Inn" sama artinya dengan "motor inn" dalam bberapa kasus dan merefleksikan pandangan banyak orang tentrang terminologi tersebut (Howel,1989:144 dalam Fay, 1992:10). Beberapa properti yang menggunakan istilah "inn" berusaha mengesankan gaya lama Eropa (Old-fashioned European image) tanpa atau dengan merubah sedikit saja atmospir dengan ruang kecil yang penuh keakraban yang biasanya dihubungkan dengan suasana di sebuah "inn". Konsequensinya adalah penggunaan istilah "inn" harus mempertimbangkan beberapa hal, sehingga ketika wisatawan datang untuk menginap mungkin memiliki ekspetasi berbeda dengan suasana yang didapatinya.

\section{Hotel}

Hotel adalah bangunan dimana tempat menginap, makanan, hiburan, dan berbagai jasa untuk keperluan pribadi disediakan dan dijual untuk umum (Star and Silva, 1990:293 dalam (Fay, 1992:10). Berdasarkan sejarah "Hotel" diasosiasikan pada pusat kota dan memiliki struktur bangunan gedung bertingkat tinggi. Perbedaan yang utama andata "hotel" dengan "motel" atau Motor inn" adalah pada tingkat layanan yang disediakan. Sebuah "hotel" biasanya menyediakan jasa layanan penuh (full-service", menawarkan berbagai layanan jasa pada wisatawan termasuk, kamar, makanan, minuman, fasilitas hiburan dan rekreasi, dan lain sebagainya. Pada beberapa dekade terakhir, istilah "hotel" disalah gunakan dan disamakan dengan istilah "lodging"

3. Motor Hotel.

Properti tipe ini memiliki kemiripan dengan sebuah hotel kecuali tempat parkir biasanya dekat dengan kamar. Pada kenyataannya, banyak motor hotel menyediakan fasilitas atau akses personal dari eksterior dan juga interior bangunan. Bangunan motor hotel biasanya bertingkat tiga atau kurang dari tiga dan berlokasi di dekat jalan raya utama yang sangat mudah dicapai oleh wisatawan yang menginginkan akses cepat bagi pelancong dengan kendaraan. Tetapi istilah "motor hotel" sudah dikaburkan selama bertahun-tahun dengan penggunaan hotel kecil sampai hotel bertingkat tinggi sehingga kehilangan makna aslinya sebagai sebuah gambaran lodging properti. Hal ini disebabkan oleh perbedaan utamanya yang dimiliki oleh kedua tipe akomodasi ini yang 
terletak pada akses parkir kendaraan, sedangkan tour operator hanya memikirkan akses parkir bagi bus-bus besar, sehingga motor hotel dan motor inn dianggap sama.

4. Motel or Motor Inn

Istilah "motel", "motor inn" dan "motor hotel" dapat saling mengganti penggunaannya saat ini. Kata "mo" dalam ketiga kata tersebut adalah singkatan dari "motor" yang berarti bahwa lokasinya dekat dengan jalan utama atau menunjukan bahwa pelanggan dapat memanfaatkan tempat parkir yang dekat dengan kamar. Perbedaan yang mungkin antara sebuah motel dan sebuah motor inn atau motor hotel adalah bahwa motel memiliki kamar yang lebih terbatas dalam hal jasa yang ditawarkan. Motel, mungkin tidak menawarkan jasa makanan, minuman, dan jasa pembersihan kamar seperti yang dijelaskan pada jasa layanan hotel sehingga sering disebut dengan "limitted-servicve" motel. Sedangkan motor inn atau motor hotel peling tidak menyediakan salah satu dari jasa tambahan tersebut.

5. Resort/resort Hotel

Resort dapat berupa hotel, motor inn, inn, atau variasi dari deskripsi ini. Hotel resort adalah sebuah tempat yang dikunjungi wisatawan untuk beristirahat, rekreasi dan menikmati hiburan. (Howel, 1989:142). Faktor yang menyebabkan sebuah resort menjadi sebuah resort adalah lokasinya yang jauh dari pusat kota, dan berada pada lokasi yang nyaman dan menyenangkan. Tipe layanan yang ditawarkan juga berbeda antara resort hotel dengan tipe akomodasi lainnya. Sebuah resort menyediakan fasilitas sedemikian rupa sehingga seorang wisatawan dapat menghabiskan waktu seluruhnya dari saat check-in sampai waktu keberangkatannya. Salah satu aspek lainnya adalah formalitasnya. Banyak resort telah mempertahankan country club yang merupakan atmosphere pada abad dua-puluhan.

6. Lodge

Lodge biasanya terletak di sebuah resort tetapi dengan ciri berbeda, diantaranya adalah formalitasnya. Oleh sebab itu sebuah "lodge" biasanya memiliki layanan jasa dan dekorasi yang tidak seformal sebuah resort.

7. Suit Hotel

Suit Hotel menyediakan akomodasi bagi pelanggannya berupa "suit" atau unit dengan banyak kamar. Kebanyakan memiliki dapur, kamar tamu atau kamar hiburan, dan memiliki sedikitnya satu kamar tidur. Banyak suits dapat mengakomodasi 6-8 orang. Suit Hotel biasanya memiliki fasilitas dan sarana rekreasi yang mewah, tetapi tidak menyediakan banyak jenis makanan dan minuman karena sudah tersedia dapur dengan peralatan yang lengkap di dalam setiap unit.

\subsubsection{Klasifikasi Lodging dan Tingkat Layanan yang ditawarkan}

1. World Class: Akomodasi jenis ini memiliki fasilitas dan jasa tidak dapat dibandingkan dengan akomodasi pada umumnya, karena itu biasanya memiliki lokasi pada pusat kota yang bergengsi. Beberapa hotel berjaringan internasional mulai menyediakan fasilitas dan jasa seperti ini, seperti hotel yang memiliki nama Ritz-Carlton dan Intercontinental.

2. First Class: Layanan first-class adalah layanan tingkat standar dalam hal fasilitas dan jasa yang ditawarkan di sebuah properti pusat kota atau pinggiran kota. Beberapa perusahaan yang dikenal konsisten menawarkan jasa first-class adalah Embassy, suits, Westin, Sheraton, Four Seasons, dan Hilton. Tetapi tentu beberapa fasilitas yang dimilikinya tidak dapat diragukan merupakan world Class.

3. Standard: Perusahaan seperti Best Western, Holiday Inn, Howard and Ramada Inn menyediakan jasa dan penampilan standards. Kebanyakan propertinya mungkin bertaraf first class tetapi berdasarkan umur propertinya, rating perusahaan seperti AAA dan Mobil sering mengkategorikannya sebagai sebuah perusahaan level standard. Banyak properti independen yang menyediakan jasa pelanggan terbatas juga dikategorikan standard.

4. Economy: akomodasi ini sering disebut dengan klasifikasi "budget", tetapi tidak berarti kamarnya tidak indah atau tidak nyaman. Akan tetapi sudah jelas menawarjan jasa makanan dan minuman yang terbatas. 


\subsubsection{Tipe Fasilitas Lodging}

a. Full-service: properti dari sebuah akomodasiyang menyediakan layanan lengkap paling tidak memiliki satu restoran yangmemiliki ijin menyediakan minuman alkohol di dalamnya. Full-service biasanya memiliki layanan kamar,termasuk jasa rekreasi seperti kolam, sauna, dan klub kesehatan.

b. Convention service: akomodasi jenis ini biasanya memiliki fasilitas sebuah restoran ditambah dengan ruang pertemuan dan ruang perjamuan serta tempat pertemuan. Ruang konvensi biasanya berbentuk persegi sesuai dengan jumlah peserta yang dapat diakomodasi dalam bentuk ruang kelas atau teater. Hotel konvensi tidak harus memiliki fasilitas ruang konvensoi sendiri, akan tetapi dapat berlokasi di dekat ruang/gedung pertemuan. Karena permintaan layanan jasa konvensi di sebuah hotel konvensi harus dilakukan dengan sangat cermat membuat layanan pribadi pada akomodasi jenis ini cederung terbatas.

c. Limited-service: Akomodasi tipe ini tidak memiliki fasilitas tempat makan atau minuman beralkohol. Beberapa dapat menyediakan makan pagi konvensional atau makanan yang dipesan di lobby. Beberapa memiliki ruang pertemuan untuk tujuan tertentu dan biasanya difungsikan untuk menydiakan layanan makan pagi. Akomodasi tipe ini tidak memiliki jasa rekreasional yang banyak tetapi sering memiliki kolam renang

d. Suit-only service: Karena dapur dan fasilitas memasak sudah lengkap maka maka restoran dan room-service biasanya tidak disediakan. Minuman beralkohol biasanya disediakan di lobby

\subsubsection{Tipe Lokasi}

Dilihat dari lokasinya, akomodasi dapat dibedakan menjadi 5 yaitu:

1. Lokasi jalan utama (Highway location); lokasi akomodasi dapat dicapai dengan cepat dan mudah dari jalan utama. Akomodasi yang berlokasi di jalan utama juga menyediakan fasilitas parkir kendaraan yang memadai dan dapat berupa hotel, motel, motor hotel, suite hotel, dsbnya.

2. Lokasi dekat Bandar Udara (Airport Location); Properti yang berada di dekat dengan bandara juga dapat berupa berbagai jenis akomodasi, tetapi lebih banyak berupa hotel atau motel bertingkat tinggi dengan tingkat pelayanan standar dan firstclass dengan berbagai jenis layanan jasa dan beberapa fasilitas pertemuan dan pesta. Beberapa tahun terakhir beberapa hotel chain berkelas ekonomi dengan layanan terbatas juga dibangun deket dengan airport dan beberapa bandara juga dilengkapi dengan suit hotel. Parkir bus biasanya menjadi masalah, kebidingan bandara juga menjadi perhatian.

3. Akomodasi yang berlokasi di pusat kota (Center-city Location) ; akomodasi yang menyasar wisatawan bisnis biasanya berlokasi di bagian pusat bisnis dari sebuah kote dan sering disebut dengan CBD (central business district) properti. Karena tipe pelanggan akomodasi ini tidak berorientasi/peduli pada harga (not price-sensitive) dan biasanya memiliki tingkat layanan first-class atau world class dan cenderung dapat menyediakan layanan tambahan lainnya dan karena itu tergolong akomodasi mahal bagi tour operator. Ketika properti ini memanfaatkan sarana parkir pemerintah kota maka itu menjadi masalah.

4. Akomodasi yang berlokasi di pinggiran kota (Suburban Location); properti ini biasanya berada di kota berukuran sedang atau bagian perkotaan dari sebuah kota besar dan dapat dibangun berupa berbagai jenis akomodasi dan dipasarkan dengan menyediakan berbagai layanan. Bagi Tour Operator, akomodasi yang berlokasi di wilayah ini merupakan pilihan yang bagus untuk lokasi yang dekat dengan pusat kota dalam hal harga dan tempat parkir.

5. Lokasi Resort (Resort Location) biasanya berlokasi jauh dari perkotaan dan karena itu harus menyediakan semua jenis layanan. Properti dan lingkungan resort yang indah menjadi Atraksi atau daya tarik bagi wisatawan. Istilah "resort" dapat digunakan untuk menunjukan tipe propertinya seperti pada klasifikasi hotel atau secara sederhana sebuah lokasi dekat dengan resort. Karena istilah resort sudah digunakan berlebihan pada industri 
maka bagi tour operator sebaiknya menanyakan apakah layanan yang diberikan mencakup seluruh jenis layanan.

\subsubsection{Dining}

Masyarakat umum mungkin mengkonsumsi makanan tiga kali sehari dengan fasilitas dan peralatan makan. Kebanyakan tour operator memasukan makan dalam paket turnya. Dan bahkan sebuah tour operator yang tidak menyediakan makan dalam paketnya juga harus memilih dan memastikan satu tempat yang memiliki fasilitas makan yang memadai bagi peserta tur. Berbagai tingkatan, tipe dan gaya jasa hidangan makanan diperlukan sebagai komplimen dalam sebuah paket wisata.

Salah satu jenis layanan restoran adalah "Table Service Restaurants" yaitu sebuah restoran yang menyediakan layanan pramusaji langsung di meja makan. Restoran jenis ini digolongkan ke dalam pelayanan yang berkualitas lebih tinggi dibandingkan dengan restoran dengan pelayanan sendiri. Kategori restoran "table Service Restaurant" adalah:

1. Restoran dengan tema kusus

2. Dinner Theater atau Rumah Teater

3. Restoran Gaya Keluarga/ ekonomi

Jenis restoran lainnya adalah Buffet/Restoran Gaya Cafetaria Tidak ada restorant yang tumbuh dan memperoleh tingkat penerimaan lebih dari masyarakat selain Buffet Restorant yaitu restoran yang menyediakan layanan makanan prasmanan. Konsepnya dekorasi yang menyerupai gaya lama sudah diganti dengan gaya modern yang mungkin kelihatan sebagus retoran terbaik. Kafetaria yang bersifat institusional sudah diganti dengan meja prasmnan yang juga dikenal dengan nama "smorgasbords". Restorant prasmanan memperoleh popularitas karena memberikan harga relatif murah dengan pilihan jenis hidangan yang banyak dengan untuk memuaskan wisatawan dengan jumlah besar.

Jenis restoran lainnya adalah restoran dengan pelayanan cepat (Quick-Service Restaurants) yang terkadang berkonotasi pada fast-food restoran, restorat layanan-cepat hanya menyediakan seperti namanya yaitu dengan memanfaatkan area "a walk-up" or “drive-through". Perusahan pertama dari kategori ini adalah McDonald's yang fokus pada makanan sejenis hamburger. Restoran serupa lainnya adalah seperti Pizza Hut, Taco Bell. Kentucky Fried Chicken, dan Wendy's.

\subsubsection{Sightseeing/Guide Service}

Sighseeing adalah produk yang ditawarkan oleh sebuah destinasi yang berkaitan dengan alam yang indah dan menarik. Kota-kota tertentu memiliki tempat-tempat budaya, sejarah, dan pendidikan. Sebuah kota juga mungkin memiliki alam dan tempat rekreasi buatan yang mengagumkan. Berpindah dari satu destinasi ke destinasi yang lain, sebuah operator perjalanan mungkin memilih untuk melakukan perjalanan melalui jalan utama dengan pemandangan indah daripada jalan baypass yang super cepat untuk memberikan kesempatan bagi para penumpang melihat-lihat pemandangan indah. Sightseeing membutuhkan seorang pramuwisata untuk menjadikannya lebih menarik. Jasa pramuwisata meningkatkan kualitas tur melalui penyertaan seorang pramuwisata yang terlatih untuk memfasilitasi sebuah tur. Sebuah tur di jalan utama dengan pemandangan indah yang ditemani oleh pramuwisata akan menyediakan layanan informasi tentang sejarah, budaya, fauna, cerita oang lokal, legenda, bangunan dan kota terdekat, dsbnya. Sebuah city tour biasanya sedikit lebih kompleks mencakup tentang informasi arsitektur, informasi sejarah, dan formasi kepemerintahan, rute spesifik, konsep warna menurut penduduk lokasl, dsbnya.

\subsubsection{Atraction}

Atraksi pada umumnya dimaksudkan pada hiburan yang membutuhkan tiket masuk dan atau pemesanan lebih awal. Disamping itu, kunjungan ke sebuah atraksi wisata paling tidak membutuhkan satu jam. Jalur khusus terkadang membedakan sebuah atraksi dan sighseeing seperti: 
1. Tur Boston, Massachusetts, adalah sighseeing; walaupun begitu; tambahan kunjungan ke New England Aquarium mungkin digabungkan dalam tur itu. Bagian Aquarium dari tur itu adalah sebuah atraksi.

2. Sebuah Tour New York City dikonotasikan sightseeing, sedangkan menaiki puncak patung liberti adalah sebuah kunjungan atraksi. Melihat patung Liberty dari jarak tertentu saja digolongkan ke dalam sighseeing.

3. Sebuah wisata naik kereta api dapat digolongkan sebagai sebuah atraksi sebagai sebuah hiburan bukan sebagai alat transportasi, khususnya digabungkan dengan hiburan lainnya seperti misteri pembunuhan.

Catatan penting adalah banyak atraksi menyediakan jasa pramuwisata dan brosur untuk membuat pengalaman wisatawan lebih menyenangkan.

\subsubsection{Shopping}

Wisatawan suka membeli cinderamata dan memberi hadiah pada orang-orang yang ditinggalkannya di rumah. Berbelanja dibedakan dengan atraksi wisata karena tidak ada biaya masuk, tetapi berbelanja dapat menghibur seperti pada atraksi. Tujuan utama dari shopping dengan atraksi berbeda. Tetapi ada kemungkinan menggabungkan atraksi dengan makan.

\subsection{Mengorganisasikan Komponen Perjalanan Wisata; Itinerary}

Sebuah itinerary adalah organisasi elemen sebuah tur yang logis, menarik, dan menggambarkan proses tahap demi tahap per hari termasuk, waktu, rute, dan komentar yang direncanakan. Pengorganisasian waktu (timing) dimaksud adalah alokasi waktu yang cukup bagi peserta tur untuk berpartisipasi di dalamnya dan perjalanan antara elemen-elemen yang direncanakan. Timing sangat tergantung pada rute yang dibuat yang menentukan jalan, jalan lintas utama, dan jalan yang dimanfaatkan dalam sebuah tur. Routing (pengorganisasian rute) harus diorganisasikan untuk perjalanan antar destinasi dan juga wisata kota. Komentar (commentary) adalah naskah yang digunakan oleh seorang pramuwisata untuk membuat perjalanan menarik selama menjalankan tur dari destinasi ke destinasi lainnya, atau selama tur di sebuah kawasan.Commentary ini juga disebut dengan "guidespeak" oleh Mancini.

Beberapa jenis itinerary diperlukan dalam setiap tur. Itinerary ringkas (summary itinerary) yang memberikan informasi tentang tempat-tempat yang paling menarik dalam tur dan berbasis harian tetapi tidak memberikan informasi tentang rute ataupun waktu. Sebuah ringkasan itinerary biasanya digunakan untuk tujuan pemasaran seperti dalam brosur. Itinerary detail ada dua tipe yaitu yang digunakan oleh peserta tur yang sering disebut dengan DPI (Detail Passenger Itinerary) dan yang digunakan pedoman oleh pramuwisata atau supir yang disebut dengan escort/driver itinerary, operating itinerary atau kadang-kadang disebut dengan manual. DPI digunakan untuk memberikan informasi detail kepada peserta tur sehingga mereka memiliki gambaran apakah mereka memiliki waktu cukup untuk makan pagi, atau berpakaian untuk acara makan karena itinerary detail memberikan informasi tentang waktu penjemputan, waktu di atraksi, dan waktu makan, serta waktu-waktu lainnya dalam setiap elemen tur. Informasi yang ada pada DPI tentu cukup untuk para peserta tetapi tidak cukup bagi pengantar, pramuwisata, atau supir. Informasi lain yang ada dalam escort itinerary adalah nama restoran, contak person di atraksi dan restorant, hotel, serta komentar. Sehingga seorang pengantar wisatawan dapat memberikan komentar dengan memadai serta menjalankan turnya dengan lancar.

\section{Penutup}

Komponen sebuah perjalanan wisata pada dasarnya ada enam yaitu sarana transportasi, tempat menginap, tempat makan, tamasya, atraksi wisata dan berbelanja. Tetapi dalam membuat sebuah paket wisata berbagai alternatif dari masing-maasing komponen tersebut dapat dikombinasikan secara berbeda sehingga berbagai alternatif paket wisata dapat dibuat. Perbedaan tersebut didasarkan pada karakteristik wisatawan. Karakteristik tersebut dapat 
berupa, jumlah wisatawan/peserta, waktu yang dibutuhkan/dimiliki peserta, biaya yang dialokasikan, jenis makanan yang diinginkan, aktivitas wisata yang dilakukan dan berbagai karakteristik lainnya. Pada akhirnya sebuah paket wisata yang baik akan mengandung keenam komponen tersebut yang kombinasinya sesuai dengan kebutuhan dan keinginan wisatawan.

Satu saran dapat direkomendasikan pada mahasiswa Jurusan Pariwisata Budaya, Program Studi Industri Perjalanan, bahwa penguasaan terhadap komponen-komponen sebuah perjalanan wisata begitu penting untuk dapat menyusun sebuah paket wisata dengan berbagai alternatif sesuai dengan potensi daerah yang dimiliki atau sesuai dengan permintaan wisatawan. Sebuah perjalanan antar negara mungkin membutuhkan sarana transportasi udara yang sama, akan tetapi sesudah di destinasi wisata memerlukan sarana transportasi wisata yang berbeda-beda sesuai dengan keinginan yang didasarkan atas pertimbangan efisiensi harga, waktu, dan ruang, serta jenis perjalanan yang dlakukan di dstinasi tersebut. Begitu juga komponen perjalanan wisata lainnya. Pengetahuan ini akan membentuk keterampilan lulusan menjadi tour manajer atau produk manajer.

\section{Daftar Pustaka}

Bagyono. 2007. Pariwisata dan Perhotelan. Bandung: Alfabeta

Fay, Betsy. 1992. Essentials of Tour Management. New York: Prentice Hall

Karyono, A. Hari. 1997. Kepariwisataan. Jakarta: Grasindo.

Pendit, Nyoman S. (2002). Ilmu Pariwisata Sebuah Pengantar Perdana. Jakarta: PT. Pradnya Paramita.

Pitana, I Gde. 1999. Pelangi Pariwisata Bali. Denpasar: Bali Post.

2005. Sosiologi Pariwisata. Yogyakarta: ANDI.

Yoeti, Oka A. 1996. Pengantar Ilmu Pariwisata. Bandung: Angkasa

2008. Perencanaan dan Pengembangan Pariwisata. Jakarta: PT. Pradnya Paramita. 